\title{
Pengobatan Penyakit Pernapasan pada Babi dalam Upaya Meningkatkan Produktivitas Ternak di Desa Penarukan, Kerambitan, Tabanan
}

\author{
(TREATMENT OF RESPIRATORY DISEASE IN PIGS IN EFFORTS TO INCREASE \\ LIVESTOCK PRODUCTIVITY IN PENARUKAN VILLAGE, KERAMBITAN, TABANAN)
}

\section{Gusti Ketut Suarjana*, Nengah Kerta Besung, Aida L.T. Rompis, Ketut Tono Pasek Gelgel}

\author{
Laboratorium Mikrobiologi Veteriner Fakultas Kedokteran Hewan Universitas Udayana. Jl. \\ PB. Sudirman Denpasar Bali. *Email: kt_suarjana@unud.ac.id
}

\begin{abstract}
ABSTRAK
Telah dilakukan pengabdian kepada masyarakat tentang pengobatan penyakit pernapasan pada babi dalam upaya meningkatkan produktivitas ternak di Desa Penarukan, Kerambitan, Tabanan. Pengabdian ini bertujuan untuk memberikan pengetahuan kepada masyarakat tentang cara mengelola ternak babi secara intensif, cara pencegahan maupun pemberantasan penyakit pada ternak babi secara efektif dan efisien sehingga hasil produksinya lebih maksimal. Metode pelayanan meliputi tindakan dari rumah ke rumah terutama ke peternak yang babinya sakit, mengadakan tindakan terapi dengan antibiotika, obat cacing, vitamin maupun mineral dan memberikan penyuluhan tentang cara mencegah penyakit pernapasan pada babi yang dikenal sebagai porcine respiratory complex desease (PRDC). Hasil yang didapatkan sebagai berikut: masyarakat memberikan respon positif terhadap kegiatan dan tim mengadakan pelayanan pada 10 peternak yang tersebar pada lima banjar banjar adat di desa Penarukan.Babi yang sakit umur berkisar 1-3 bulan dan jumlah yang diobati 20 ekor. Selanjutnya berdasarkan pemantauan tim dan laporan peternak pada hari ke tujuh setelah diberi pengobatan babibabi tersebut tidak menunjukkan gejala klinis dan dinyatakan sembuh.
\end{abstract}

Kata kunci: Babi, PRDC.

\begin{abstract}
Community service has been conducted on the treatment of respiratory diseases in pigs in an effort to increase livestock productivity in Desa Penarukan, Kerambitan, Tabanan. This dedication aims to provide knowledge to the community about how to manage pigs intensively, the prevention and eradication of diseases of pigs effectively and efficiently so that the maximum production of the livestock. Methods of service include house-to-house acts, especially to sickly breeders, initiating treatment with antibiotics, worm medicines, vitamins and minerals and providing counseling on how to prevent respiratory respiratory complex desease (PRDC) disease in pigs known as porcine respiratory complex desease (PRDC). The result obtained as follows: the community is give a positive response to activities and teams held home-to-home services to tens of breeders pigs whose reportedly suffered from PRDC spread over five banjar adat in Penarukan village. The sick pigs generally ranged from 1 to 3 months and treated as many as 20 . Furthermore, based on the monitoring of the team and the report of breeders on the seventh day after being given treatment of the pigs showed no clinical symptoms and was declared cured.
\end{abstract}

Keywords: Pig, PRDC.

\section{PENDAHULUAN}

Secara tofografis, desa Penarukan merupakan daerah yang potensial untuk mengembangkan ternak babi, sapi maupun unggas. Desa Penarukan berada pada ketinggian sekitar 100-200 meter diatas permukaan laut berdampingan dengan Desa
Sudimara yang telah memperoleh kunjungan oleh tim udayana mengabdi dalam pengemban tugas tri darma perguruan tinggi khususnya pengabdian kepada masyarakat (Suarjana et al., 2015). Desa Penarukan terdiri dari lima Banjar Adat yaitu Banjar Penarukan Kaja, Banjar Penarukan Tengah Kaja, Banjar Penarukan 
Tengah Kelod, Banjar Penarukan Kelod dan Banjar Penarukan Bantas. Jumlah kepala keluarga sekitar 800 dengan jumlah penduduk sekitar 4000 jiwa. Pada umumnya penduduk Desa Penarukan memiliki mata pencaharian sebagai petani, peternak dan pedagang. Pembangunan di bidang ekonomi di Desa Penarukan dapat dikatakan mengedepankan konsep hulu ke hilir yakni membangun berbagai potensi desa secara mandiri tanpa meninggalkan jati diri sebagai desa dengan basis pertanian. Sebagian besar masyarakat di Desa Penarukan memilih ternak babi sebagai prioritas dalam upaya menunjang ekonomi keluarga dan juga dijadikan tradisi dalam menopang kegiatan upacara keagamaan. Populasi ternak babi di Desa Penarukan diperkirakan mencapai 1200 ekor yang tersebar secara mandiri ataupun kelompok. Masingmasing keluarga memelihara ternak babi berkisar 2-4 ekor dengan sistem pemeliharaan bersifat semi intensif. Disamping itu ada beberapa kepala keluarga memelihara babi berjumlah 15 -30 ekor. Para perternak belum memahami jenis pakan dan pola pemberian pakan, sanitasi, pencegahan maupun penanganan terhadap penyakit (Agustina et al., 2016).

Dalam mengelola ternak babi kendala yang selalu dihadapi oleh para peternak yakni penyakit saluran pernapasan terutama menyerang babi muda sebelum dan setelah disapih yang disebabkan oleh agen patogen seperti bakteri maupun virus yang dikenal dengan porcine respiratorydisease complexatau PRDC (Muro et al., 2014). Lebih lanjut dikatakan bahwa agen patogen pada saluran pernapasan babi merupakan ancaman yang serius pada industri ternak babi. Kejadian penyakit PRDC sering terjadi pada babi umur 5-6 minggu (Nedbalcova et al., 2006). Penyakit saluran pernapasan komplek ini dipicu oleh beberapa faktor seperti sanitasi dan manajemen yang jelek, penuh sesak dalam kandang, perubahan cuaca maupun faktor kelelahan. Menurut Muro et al. (2015) beberapa bakteri yang berpotensi patogen pada saluran pernapasan babi meliputi Actinobacillus pleuropneumoniae, Streptococcus suis, Pasteurella multocida,
Bordetella bronchiseptica, Hemophilus parasuis dan Mycoplasma hyopneumoniae. Agen oleh viral meliputi porcine reproduktive and respiratory syndrome virus (PRRSV), swine influenza virus (SIV) dan porcine circovirus type 2 (PCV2). Penyakit PRDC ditularkan melalui aerosol dan kontak langsung dengan penderita. Gejala klinis pada babi meliputi demam, anoreksia, batuk-batuk disertai adanya eksudat dari lubang hidung. Kerugian yang timbul berupa kerugian ekonomi, penurunan berat badan dan kematian (Dosen et al., 2007).

Menurut Ardana (2004) ada lima tindakan yang saling berkaitan dalam manajemen kesehatan ternak yang dikenal dengan panca usada satwa. Tindakan-tindakan tersebut meliputi: menjaga bibit tetap sehat, menjaga kandang higienis dan nyaman, memberi pakan yang seimbang, mencegah dan memberantas penyakit dan mengelola usaha ternak dengan baik.Sistem pemeliharaan ternak memegang peranan penting dalam upaya meningkatkan produktivitas ternak. Dalam melakukan tindakan terapi terhadap infeksi agen bakteri pada saluran pernapasan babi harus menggunakan antibiotika pilihan dan bersepektrum luas. Beberapa antibiotika pilihan yang dapat digunakan seperti bacitrasin, baytril dan eritromisin (Priadi et al., 2004). Menurut Suarjana et al. (2015) beberapa antibitika pilihan untuk terapi penyakit PRDC seperti ampisilin, kanamisin, doksisiklin dan streptomisin. Pemberian antibiotika dalam upaya pencegahan penyakit maupun pemberantasan penyakit yang tidak terkontrol atau tidak prosedural dapat menyebabkan resistensi bakteri terhadap antibiotika. Peternak babi di Desa Penarukan pada umumnya belum tahu tentang cara pencegahan dan pemberantasan penyakit serta tata cara pemberian pakan yang benar sehingga produksi ternaknya belum maksimal. Peternak semi intensif adalah peternak yang belum optimal mengusahakan ternaknya secara intensif baik kualitas manajemennya maupun kuantitas ternak yang dipelihara. Para peternak tradisionil maupun semi intensif ini penting untuk diberikan informasi pengetahuan ilmiah yang praktis berupa penyuluhan dan pelayanan 
sehingga produksi ternaknya menjadi lebih maksimal.

\section{METODE PENELITIAN}

Metode kegiatan yang dilakukan untuk memecahkan masalah adalah dengan memberikan penyuluhan dan pelayanan secara langsung ke para peternak sesuai dengan informasi dari masyarakat. Kegiatan pelayanan kesehatan diprioritaskan untuk ternak babi secara klinis khas menderita PRDC dengan tindakan terapi antibiotika, pemberian vitamin/mineral atau obat diare.Dalam program penyuluhan ini akan disampaikan pengetahuanpraktis tentang pentingnya tata cara mengelola ternak babi secara intensif, dampak ekonomi maupun kesehatan ternak babi dan penerapan program pengobatan yang tepat dan efisien untuk menghindari dampak negatif dari penggunaan obat.

\section{HASIL DAN PEMBAHASAN}

Berdasarkan hasil dari tim udayana mengabdi yang telah melakukan sosialisasi kegiatan pengabdian di Desa penarukan, Kerambitan, Tabanan memperoleh data peternak babi meliputi Br. Penarukan Kelod, Br. Penarukan Bantas, Br. Penarukan Kaja, Br. Penarukan Tengah Kelod dan Br. Penarukan Tengah Kaja dengan jumlah peternak babi berturut-turut: 33, 26, 20, 11 dan 7 peternak (data terlampir).

Selanjutnya tim telah melakukan kegiatan pengabdian tgl 2 Oktober 2017 dengan melakukan penyuluhan dan pelayanan kesehatan secara langsung kepada para peternak babi di Desa Penarukan terutama yang belum memahami manajemen cara beternak babi dan kesehatan ternak babi. Tim udayana mengabdi telah memebagikan mineral 10 sebanyak $0,5 \mathrm{~kg}$ kepada setiap peternak dengan jumlah sekitar 97 peternak untuk membantu tambahan suplemen mineral dalam upaya mencegah kekurangan gizi ternak babi. Tim juga telah melakukan tindakan terapi secara langsung ke ternak babi yang sakit sesuai dengan laporan oleh masing-masing kepala dusun di Desa Penarukan.

Berdasarkan hasil laporan kepala dusun atau masyarakat di Desa Penarukan, Kerambitan Tabanan terdapat 10 peternak babi (dalam tabel) yang melaporkan babinya menderita sakit pernapasan yang wajib dikunjungi tim pengabdian dan mengadakan tindakan terapi serta penyuluhan tentang kesehatan ternak babi. PRDC merupakan penyakit saluran pernapasan yang komplek pada babi yang disebabkan oleh beberapa mikroorganisme seperti bakteri, virus dan jamur. Kejadian PRDC dapat dipicu oleh adanya stres, kekurangan vitamin dan mineral atau adanya penyakit lain seperti cacing. Tindakan terapi yang dilakukan meliputi pemberian mineral, vitamin, obat cacing dan antibiotika.

Babi sakit pernapasan menunjukkan gejala klinis demam. anoreksia,keluar eksudat dari lubang hidung. diare. malas bergerak dengan kepala menundukdan kadang-kadang disertai eritema pada kulit didaerah kepala dan punggung. Tindakan yang dilakukan terhadap ternak babi yang sakit tersebut meliputi pemberian antibiotik Betamox LA $\left(\right.$ Norbrook $\left.^{\mathrm{R}}\right)$ injeksi, injeksi obat cacing Wormectin $\left(\right.$ Medion $^{\mathrm{R}}$ ), injeksi vitamin B komplek Heksaplex.

Wormectin injeksi adalah sediaan yang efektif untuk mebasmi cacing nematoda dan ektoparasit seperti tungau, kutu, caplak dan insekta lainnya. Dalam leaflet wormectin dari Medion menyebutkan wormectin injeksi mengandung 22,23dihydroavermectin B14 dan 22,23dihydroavermectin B15 yang memiliki aktivitas sebagai antelmitik atau membunuh cacing. Sedangkan Betamox LA mengandung antibiotik Amoxicillin yang tergolong antibiotika berspektrum luas efektif untuk membunuh bakteri termasuk Escherichia coli patogen, beberapa bakteri Gram negatif lainnya yang patogen pada saluran pernapasan seperti Haemophilus parasuis dan Pasteurella sp. 
Tabel 1 Nama para peternak babi di desa Penarukan, Kerambitan, Tabanan yang dikunjungi dan mendapat pelayanan kesehatan

\begin{tabular}{|c|c|c|c|c|c|}
\hline No. & Nama Peternak & Alamat & $\begin{array}{l}\text { Jml } \\
\text { Babi } \\
\text { (ekor) }\end{array}$ & $\begin{array}{l}\text { Jml. } \\
\text { Babi sakit } \\
\text { (ekor) }\end{array}$ & Tindakan \\
\hline 1 & $\begin{array}{l}\text { I Wayan Agus } \\
\text { Yana }\end{array}$ & $\begin{array}{l}\text { Br. Penarukan } \\
\text { Kelod }\end{array}$ & 5 & 2 & $\begin{array}{l}\text { Terapi inj.a.b,inj obat } \\
\text { cacing,Vit, Mineral. }\end{array}$ \\
\hline 2 & $\begin{array}{l}\text { I Wayan Darma } \\
\text { Asdtawa }\end{array}$ & $\begin{array}{l}\text { Br. Penarukan } \\
\text { Kelod }\end{array}$ & 4 & 2 & $\begin{array}{l}\text { Terapi inj.a.b,inj obat } \\
\text { cacing,Vit, Mineral. }\end{array}$ \\
\hline 3 & $\begin{array}{l}\text { I Putu Agus Eka } \\
\text { Swardana }\end{array}$ & $\begin{array}{l}\text { Br. Penarukan } \\
\text { Bantas }\end{array}$ & 6 & 2 & $\begin{array}{l}\text { Terapi inj.a.b,inj obat } \\
\text { cacing,Vit, Mineral. }\end{array}$ \\
\hline 4 & $\begin{array}{l}\text { I Nyoman } \\
\text { Sukadana }\end{array}$ & $\begin{array}{l}\text { Br. Penarukan } \\
\text { Bantas }\end{array}$ & 10 & 2 & $\begin{array}{l}\text { Terapi inj.a.b,inj obat } \\
\text { cacing,Vit, Mineral. }\end{array}$ \\
\hline 5 & $\begin{array}{l}\text { Nyoman } \\
\text { Suardana }\end{array}$ & $\begin{array}{l}\text { Br. Penarukan } \\
\text { Kaja }\end{array}$ & 3 & 1 & $\begin{array}{l}\text { Terapi inj.a.b,inj obat } \\
\text { cacing,Vit, Mineral. }\end{array}$ \\
\hline 6 & Ketut Sukarata & $\begin{array}{l}\text { Br. Penarukan } \\
\text { Kaja }\end{array}$ & 2 & 1 & $\begin{array}{l}\text { Terapi inj.a.b,inj obat } \\
\text { cacing,Vit, Mineral. }\end{array}$ \\
\hline 7 & $\begin{array}{l}\text { I Gusti Ketut } \\
\text { Sujaya }\end{array}$ & $\begin{array}{l}\text { Br. Penarukan } \\
\text { Tengah Kelod }\end{array}$ & 10 & 4 & $\begin{array}{l}\text { Terapi inj.a.b,inj obat } \\
\text { cacing,Vit, Mineral. }\end{array}$ \\
\hline 8 & Made Awidya & $\begin{array}{l}\text { Br. Penarukan } \\
\text { Tengah Kelod }\end{array}$ & 4 & 2 & $\begin{array}{l}\text { Terapi inj.a.b,inj obat } \\
\text { cacing,Vit, Mineral }\end{array}$ \\
\hline 9 & $\begin{array}{l}\text { Kade } \\
\text { KertaWinaya }\end{array}$ & $\begin{array}{l}\text { Br. Penarukaan } \\
\text { Tengah Kaja }\end{array}$ & 7 & 2 & $\begin{array}{l}\text { Terapi inj.a.b,inj obat } \\
\text { cacing,Vit, Mineral }\end{array}$ \\
\hline 10 & $\begin{array}{l}\text { Nyoman } \\
\text { Narayana }\end{array}$ & $\begin{array}{l}\text { Br. Penarukan } \\
\text { Tengah Kaja }\end{array}$ & 10 & 2 & $\begin{array}{l}\text { Terapi inj.a.b,inj obat } \\
\text { cacing,Vit, Mineral }\end{array}$ \\
\hline
\end{tabular}

Keterangan $:$ jml $=$ jumlah, inj. $=$ injeksi, a.b.= antibiotika, vit. $=$ vitamin

$\left(\right.$ Bernofarm $^{\mathrm{R}}$ ), obat cacing saset Contra-Worm $\left(\right.$ Pyridam $^{\mathrm{R}}$ ) dan mineral Min.10.
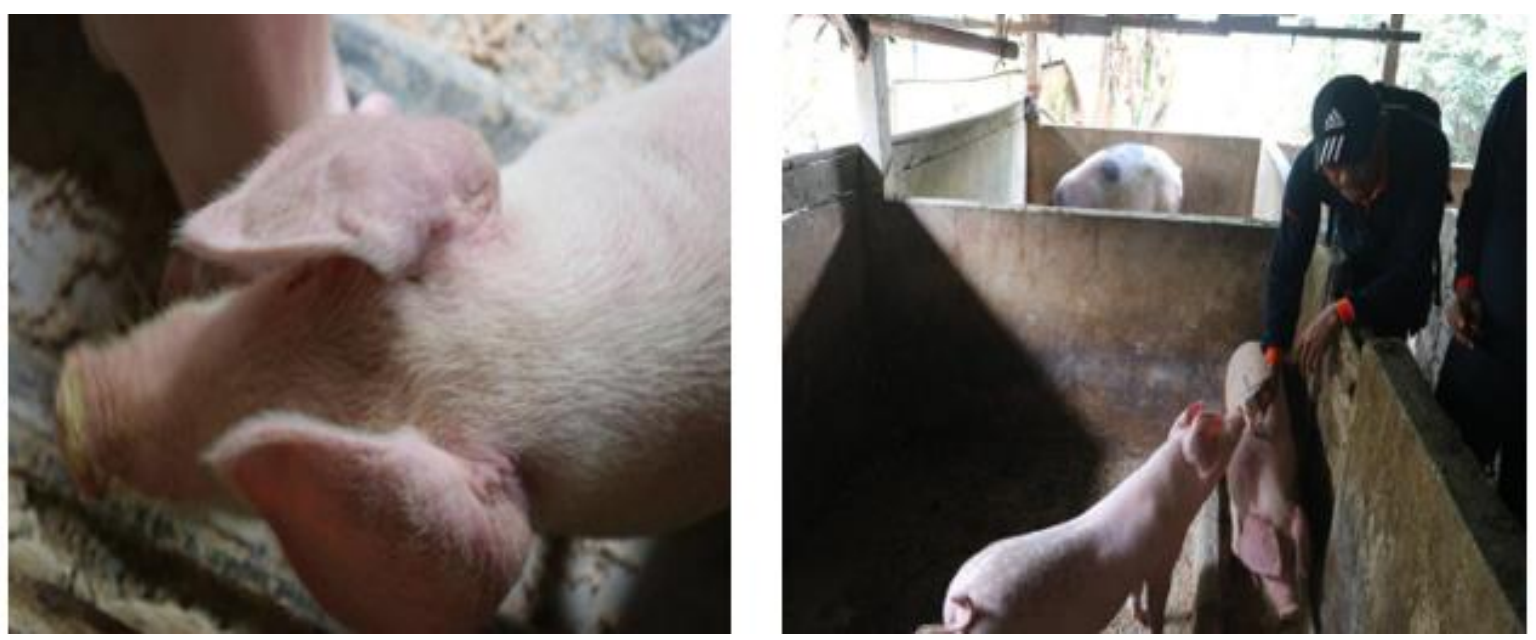

Gambar 1. Kondisi babi (kiri) dan proses penanganan kesehatan babi (kanan)

Jumlah babi yang menderita sakit pernapasan, demam dan anoreksia berkisar 20 ekor. Ternak babi yang menderita diare tapi tidak persisten, tidak demam dan masih mau makan diberikan obat cacing saset Wormectin dan mineral Min.10. Tim mencatat bahwa babi yang menderita sakit umur berkisar 1-3 bulan . Tindakan lain yang diberikan oleh tim pengabdian berupa penyuluhan atau penjelasan-penjelasan singkat tentang manajemen kesehatan ternak terutama cara mencegah dan 
mengobati penyakit saluran pernaapasan pada babi. Materi penyuluhan ditekankan pada pentingnya menjaga sanitasi kandang secara intensif dan pentingnya peranan dokter hewan dalam melakukan tindakan terapi terhadap penyakit pada ternak sehingga pemakaian antibiotika dapat dilakukan dengan benar, terkontrol dan bertanggungjawab.

Selanjutnya tim mengadakan monitoring dan evaluasi terhadap ternak babi yang sakit saluran pernapasan dengan mencatat gejala klinis dan nafsu makan. Berdasarkan pantauan tim pengabdian dan laporan para peternak satu minggu setelah melakukan kegiatan diperoleh hasil bahwa tindakan-tindakan yang dilakukan oleh tim cukup efektif. Hal ini dapat dibuktikan dengan adanya respon positif para peternak dan melaporkan babinya sembuh dari penyakit saluran pernapasan.

\section{SIMPULAN}

\section{Simpulan}

Berdasarkan hasil kegiatan pengabdian masyarakat di Desa Penarukan, Kerambitan, Tabanan, maka dapat disimpulkan bahwa para peternak sangat antusias dan memberi respon positif terhadap kegiatan, tindakan yang dilakukan oleh tim pengabdian cukup efektiv oleh karena babi yang sakit menjadi sembuh dan para peternak menjadi sadar akan dampak kerugian ekonomi penyakit pernapasan pada babi.

\section{Saran}

\begin{tabular}{lrr}
\multicolumn{1}{c}{ Kegiatan pengabdian } & $\begin{array}{r}\text { kepada } \\
\text { dapat }\end{array}$ \\
masyarakat diharapkan & dalam & upaya \\
berkesinambungan gairah para peternak, \\
meningkatkan gan \\
produktivitas ternak maupun kesejahtraan \\
peternak.
\end{tabular}

\section{UCAPAN TERIMAKASIH}

Tim pengabdian kepada masyarakat menyampaikan ucapan terimakasih kepada dinas pemerintah yang terkait yang telah memberi dukungan pada kegiatan ini. Ucapan terimakasih yang sebesar-besarnya juga kami ucapkan kepada Yth.Bapak
Kepala Desa Penarukan, Kerambitan, Tabanan beserta staf yang telah membantu kegiatan sehingga dapat berjalan lancar dan sukses. Tidak lupa juga kami menghaturkan terimakasih yang tidak terhingga kepada yang terhormat Kepala LPPM Universitas Udayana beserta staf yang telah memberi dukungan moril maupun materiil sehingga kegiatan pengabdian ini dapat berjalan dengan lancar.

\section{DAFTAR PUSTAKA}

Agustina KK, Wirata IW, Dharmayudha AAGO, Kardena IM, Dharmawan NS. 2016. Increasing farmer income by improved pig management systems. Buletin Veteriner Udayana. 8(2): 122127.

Ardana IB. 2004. Penerapan Panca Usada Satwa Untuk Kesehatan Babi. Laboratorium Manajemen dan Penyakit Babi. Fakultas Kedokteran Hewan Universitas Udayana.

Dosen RJ, Prodanov D, Milanov I, Stojanov, Pusic I. 2007. The bacterial infection of respiratory tract of swine. Biotecnol. Anim. Husbandry. 23(5-6): 237-243.

Loera-Muro VM, Loera-Muro A, MorfinMata M, Jacques M, Avelar-Gonzales F, Ramirez-Castillo F, Ramirez-Lopez EM, Guerrero-Barrera A.. 2014. Porcine respiratory pathogen in swine farms environment in Mexico. Open J. Anim. Sci. 4: 196-205.

Nedbalcova K, Satran P, Jaglic Z, LoeraMuro A, Ramirez-Castillo FY, AvelarGonzalez FJ, Guerrero-Barrera AI. 2015. Porcine respiratory disease complex and biofilm. J. Bacteriol Parasitol. 6(6): 1000247.

Ondriasova R, Kucerova Z. 2006. Haemophilus parasuis and Glasser's disease in pigs: a review. Veterinarni Medicina. 51(5): 168-179.

Priadi A, Natalia AL, Poernomo S, 2004. Glasser's disease in swine in Batam Island, Riau Province. JITV. 9(4): 266277. 
Suarjana IGK, Tono PG, Suwiti NK, Apsari IAP. 2015. Pengobatan penyakit diare (kolibasilosis) pada babi dalam upaya meningkatkan produktivitas ternak di desa Sudimara, Tabanan. Laporan Pengabdian Kepada Masyarakat
Dibiayai oleh DIPA PNPB Universitas Udayana.

Suarjana IGK, Besung INK, Tono K, 2016. Deteksi dini hemophilus parasuis pada saluran pernapasan babi. Hibah Unggulan Program Studi DIPA PNBP Universitas Udayana 